\title{
Public Administration and Good Governance
}

\section{Mäenpää, Olli Ilmari}

Springer

2019

Mäenpää , O I \& Fenger , N 2019 , Public Administration and Good Governance . in P Letto-Vanamo, D Tamm \& B O Gram Mortensen (eds), Nordic Law in European Context . lus Gentium: Comparative Perspectives on Law and Justice, vol. 73 , Springer, Cham , pp. 163-178 . https://doi.org/10.1007/978-3-030-03006-3_10

http://hdl.handle.net/10138/309551

https://doi.org/10.1007/978-3-030-03006-3_10

unspecified

acceptedVersion

Downloaded from Helda, University of Helsinki institutional repository.

This is an electronic reprint of the original article.

This reprint may differ from the original in pagination and typographic detail.

Please cite the original version. 


\section{Public Administration and Good Gov- ernance*}

\section{Abstract}

The Nordic countries share broadly similar rules and principles of administrative law. Although the administrative laws of Denmark, Norway and Iceland have much in common, they differ in important respects from the public law of Finland and Sweden, so that one may speak of two groups of public law. Executive power and the conditions for its exercise have also been regulated in constitutional acts, more so for Finland and Sweden than for Denmark and Norway. In all the Nordic countries legalism maintains its significance in the exercise of administrative functions although in the provision of public services, legalism is somewhat more subdued.

\section{Introduction}

\subsection{The Structure of Administration}

In the Nordic countries, the core of the central state administration is formed by a combination of ministries and independent administrative agencies. It is the general responsibility of the ministries to supervise and control the subordinate state administration, but their duties also include making individual decisions of major importance in a number of administrative activities. Territorial organization is based on provinces and regions at the intermediate level and municipalities and districts at the local level. Provinces and districts are integral parts of state administration while municipalities and the regions constitute units of self-government.

\footnotetext{
* By Olli Mäenpää, Professor, University of Helsinki, and Niels Fenger, Professor and Judge at the Eastern Court of Appeal, Denmark.
} 
The national (state) level is primarily responsible for such general public services as research, defence and the police. Local administration, based on autonomous municipalities or regions, is responsible for individual services such as healthcare, social services and basic education. The state administration exercises supervision and evaluation of public services. Moreover, as a rule the central authorities may only intervene in decisions taken by local and regional authorities to the extent that their decisions can be considered illegal.

In other respects, the organization of the administrative apparatus differs. A specific characteristic of Swedish and Finnish administrative law is that administrative structures are not fully centralized. Administrative agencies and public officials are required to act independently and solely on the basis of legal regulation. In the exercise of their authority they therefore enjoy distinctive independence with regard to superior authorities and the instructive power they might want to exercise. Public officials are also individually accountable for their decisions.

Since decisions are made independently, a ministry is considered to lack the power to intervene directly in an agency's decision-making in individual cases or in an agency's day to day operations. Similarly, a public official is expected to use their powers autonomously and without direct interference by a superior official. A ministry which considers that an agency's application of law in individual cases is incorrect or undesirable may try to change it only by amending the applicable rules. The ministry may also issue general policy instructions.

In this respect, the other legal systems follow the more traditional European model, as the general rule in these countries is that a minister may give orders as to how a subordinate directorate should decide an individual case. Moreover, when applying rules that give the authorities discretion, that discretion must be applied in a manner that complies with the policy of the government. within the framework set out by legislation and general principles of law. That being said, in a few fields of administrative law special legislation prescribes that a given case should be decided by an independent agency, with the effect that the minister may not intervene in the decision-making process.

Another major difference between the various legal systems is that Sweden and Finland have special administrative courts whereas Denmark, Norway and Iceland have a single judicial system which, especially in Denmark, is 
supplemented by a wide range of administrative complaint bodies. See, in this respect, point 5.1 below.

\subsection{The Nordic Welfare Model and Administrative Regulation}

The duties and powers of administrative organs vary by their contents and their nature in different fields of administration and in different activities. At the beginning of the $20^{\text {th }}$ century, the main duty of authorities was administrative regulation based on the application and enforcement of law in individual cases. This still has an essential significance in the activity of authorities, but in the welfare state the quantitative emphasis of activities has shifted to providing social benefits and public services. Public administration has also become more involved in economic activities. At the same time the administrative machinery has grown considerably and become more complicated and fragmented.

The forms and procedure used and the lines of action applied by administrative organs depend greatly on what kind of administrative duty is concerned. Administrative regulation is by definition based on unilateral decision-making and characteristically takes the form of written administrative decisions or administrative acts of various kinds such as administrative permits, legitimations and injunctions. Regulatory methods of more general scope such as rule-making, standard-setting and planning are also frequently used.

In addition to regulation, public services form another major field of administrative activity. Public administration still remains the central provider of public services and benefits but in most of the Nordic countries outsourcing has gradually strengthened the role of private actors, procurement and competition. When the administration performs economic functions its procedures have more or less adjusted to the models of private economic operators. This is, to a large extent, subject to competition laws and regulation concerning public procurement.

An essential element of Nordic welfare society is that municipalities play the predominant role in provision of public services. Most of the expenditure of local and regional authorities arises from providing basic community services, such as social services and healthcare, education and cultural services, infrastructure maintenance and environmental protection. 


\section{Legal Framework}

\subsection{Rule of Law and the Executive}

In many respects, the Nordic countries have broadly similar rules and principles of administrative law. At the same time, however, it is essential to observe certain fundamental differences. Traces of history are clearly discernible in the field of public law. Indeed, although the administrative laws of Denmark, Norway and Iceland share much in common, they differ in important respects from the public law of Finland and Sweden, so that one may speak of two groups of public law. Many of the differences can be traced back to the fact that Denmark and Norway (including Iceland) were united under the same King and ruled from Copenhagen, whereas Finland was part of Sweden until 1809.

A common characteristic of all the Nordic countries is that both French and German law have been a source of inspiration for the development of several principles of administrative law, such as the proportionality principle and the range and limits of judicial review. Moreover, German and French legal literature has afforded valuable methodical patterns for the conceptualization of Nordic administrative law by providing concepts and structures for describing and developing legal principles. ${ }^{1}$

Legalism and strict adherence to law have traditionally occupied a central role in Sweden and Finland, more so than in the other Nordic countries. To be sure, formal legalism has been substituted by more goal-oriented and valuebased objectives in the welfare state. Yet in all countries legalism maintains its significance in the exercise of administrative functions. With respect to public administration, the rule of law requires that the executive powers of any administrative authority must possess an express basis in law, while the exercise of public power must be justified on grounds laid down by law. The principle applies especially when an administrative authority (e.g. Ministry, agency, municipality or public official) makes administrative decisions or other acts that directly affect individual rights and obligations. The rule of law is thus a necessary prerequisite in all exercise of administrative authority. In the provision of public services, legalism is somewhat more subdued but a legal basis is still necessary for any social benefit or service.

In practice, the rule of law entails, among other things, that administrative authorities have no general competence to perform their duties. For instance,

\footnotetext{
${ }^{1}$ Fenger 2004; Revsbech 2016; Graver 2015; Strömberg \& Lundell 2014; Mäenpää 2018.
} 
although the main duty of the police force is to uphold public order and security, any intervention by the police in the sphere of private activities must be supported by an express legal basis in each individual case. The principle of conformity to law also denotes that the decision-making power cannot be based solely on administrative regulations, guidelines, instructions or plans. It is the duty of an authority within its sphere of competence to apply the law. It is another matter that administrative regulations and directives can guide decision-making, provided that this kind of supervision is based on a sufficiently precise rule establishing the power to issue such directives. In addition, internal administrative policy or strategy are to be complied with within the bounds set by law.

Executive power and the conditions for its exercise have also been regulated in constitutional acts, more so for Finland and Sweden than for Denmark and Norway. The constitutionalization of the executive function in the two former countries includes several qualitative requirements of significance. For example, the Finnish Constitution stipulates that all public action must be authorized by law, the law must be strictly complied with in the exercise of any public activity, the executive must comply with the qualitative requirements of good, transparent and accountable administration; in addition, access to the court must be available for any administrative decision concerning a right or duty. According to the Constitution, it is the duty of a public authority (the authorities) to ensure that fundamental and human rights are implemented and protected. In addition, autonomous arrangements, notably in the broad area of municipal self-government, must be respected by both the legislature and the executive, while any transfer of administrative duties to the private sphere can only occur if protection of fundamental rights, good administration and access to justice are duly guaranteed. In comparison, the Danish Constitution is much more silent in these respects and leaves most of these matters to the discretion of the legislator. ${ }^{2}$

Although the above-mentioned requirement in the Finnish Constitution may be said to represent a relatively conventional list by modern constitutional standards, it appears that the basic tenets of that constitutionalized administration have recently been subject to considerable pressures, both domestic and European.

First, the relative autonomy of the administration has been growing, especially with respect to legislative control. This is due to several interconnected

\footnotetext{
${ }^{2}$ Christensen, Albæk Jensen and Hansen Jensen 2012.
} 
factors. Detailed legislative regulation quite simply faces limits based on knowledge, technical exigencies, the need to reach political compromises and the like. Transfer of legislative powers to the European level, public-private partnerships and increased use of private or semi-private regulation have not alleviated these problems. This has all resulted in strengthening the role of the executive as the provider of practical problem-solving based on the interpretation and application of law - not only in the traditional form of unilateral decision-making but more often in a negotiated, horizontal mode based on partnership and participation.

Second, to a varying degree all the Nordic countries share a clear, and perhaps partly concomitant, shift from executive government to public governance. This reflects several significant developments ranging from a change of mindset concerning the role of the "public" in public administration to a transformation of the traditional executive function into public governance. Administration exercising public governance is based, for example, on partnership and association and hybrid forms of decision-making denoting problemsolving in a predominately administrative setting instead of execution of laws. Third, the emergence and strengthening of multi-level European governance based on an interplay between committees, networks, European and national agencies, shared governance and the like has probably strengthened the position of national administrations while simultaneously, in Finland at least, the inter-linkages have weakened national accountability, which is regulated by the Constitution.

It is not apparent that these pressures and the inroads they are capable of making into the constitutional setting of the role and function of public administration have so far been duly recognized. Whether constitutional premises and requirements can accommodate all these transformations, or whether they in fact erode constitutional norms that are designed to ensure administration that is fair, transparent, accountable and based on law, is still an open question. So far, it seems that, perhaps paradoxically, the recent constitutionalization of the administration has been of quite limited significance in this respect.

Additionally, a clear trend is evident towards an increasingly digital administration. First, all Nordic countries have introduced rules that permit, and in some cases oblige, citizens and business to interact with the administration by way of digital communication. The most far-reaching regime is in Denmark where the administration may, in all types of civil cases, and save for a few narrowly defined situations, send most types of communication to special 
e-boxes that citizens and businesses are obliged to set up. Moreover, a large number of acts have been introduced according to which the citizen may only apply digitally for permits, services and the like, typically by entering the relevant authority's webpage and filling out an electronic form. ${ }^{3}$

Second, decisions are increasingly taken either solely by a computer, as is the case for more simple tax matters, or via a system where a computer provides support to a physical case handler, e.g. by providing checklists and suggestions as to how a decision should be decided and formulated.

Third, the influence of data protection regulation is to an increasing degree felt in national administrations. In some respects the basic values underlying data protection only corroborate what already follows the traditional principles of administrative law. In other respects a certain tension might arise.

\subsection{Basic Legal Principles of Nordic Administration}

In addition to normative legal regulation, several legal principles enjoy a central role in the administrative activities of all the Nordic countries. These administrative law principles provide a qualitative value basis for administrative authorities in interpreting and applying the law. The principles function mainly as guidelines and constraints in using discretionary administrative powers, but they may also assist in the interpretation of other types of legal provisions. The principles may be relied on by individuals in administrative procedures, and as such they can also be asserted in both judicial and administrative proceedings related to administrative decisions. Administrative decisions taken in breach of these principles may be annulled or revoked by the courts.

Prominent administrative law principles include impartiality, equality, proportionality, prohibition of abuse of power, and protection of legitimate interests. While these principles were originally developed in administrative law doctrine and judicial practice, many of them have gradually been assigned a more binding legal role by elevating them to constitutional entitlements or by regulating them in written legislation. ${ }^{4}$

In Finland, the leading principles have been codified in the Administrative Procedure Act. Pursuant to Section 6, "An authority shall treat the customers of

\footnotetext{
${ }^{3}$ Fenger 2014.

${ }^{4}$ See in general Marcusson 2005.
} 
the administration on an equal basis and exercise its competence only for purposes that are acceptable under the law. The acts of the authority shall be impartial and proportionate to their objective. They shall protect legitimate expectations as based on the legal system." Similar obligations exist more or less implicitly in the other Nordic legal systems.

The general principle of equality means that similar situations must not be treated differently, unless an objectively justified cause exists for doing so. Discrimination or favouritism, for example, on the basis of origin, religion, sex, age, political or social views, trade union activity or for other similar reasons is prohibited. A similar procedure and a consistent approach must be complied with in similar cases, although for a justified reason an authority may also change its practice if that practice is to be followed consistently.

Impartiality means that only factors objectively relevant to the case may be taken into account. Decision-making and other official activities of an authority must also otherwise be impartial and independent. This principle has acquired concrete form in, for example, bias provisions emphasizing the neutrality of administrative action. According to these provisions, an official will be disqualified if confidence in their impartiality is at risk for a particular reason.

The principle of proportionality requires that a reasonable relationship should be observed in all circumstances between the relative importance of the ends pursued and the means put into operation. Consequently, the exercise of public authority must be determined appropriately in relation to the desired objectives. Such a determination can usually be made on the basis of the general interest involved and the reasonableness of the activity in attaining it.

All abuse of power (including discretionary power) is prohibited. According to this principle, the administration must not pursue a purpose other than that for which the corresponding power has been conferred. A decision taken for purposes other than those stated may constitute an abuse of power, even if the decision as such falls within the powers of the authority.

To guarantee protection of legitimate interests, administrative authorities are expected to act lawfully and predictably. Administrative decisions can not normally have retroactive effect. However, for example, revocation of a licence or a benefit is possible provided that it has a legal basis. Legitimate expectations may be created by consistent administrative practice and they 
may also be based on information or advice supplied by an official. A person can rely on justified expectations only if they have acted legitimately, for instance, by submitting correct information.

\subsection{European Framework}

In the Nordic countries, a significant part of national legislation derives, fully or partially, from European Union (EU) law. It is therefore easy to understand that the public administration of each Nordic country is a quite closely interconnected element of European administration. However, a considerable degree of national autonomy remains with regard to procedures, structures and judicial review. On the other hand, the European Court of Human Rights (ECtHR) has also been active through its case law in defining certain standards for national administrative laws. The focus of its judicial activity has been on issues such as access to justice in cases concerning executive application of the law, the quality of legal protection afforded to subjects of administrative decision-making, and the effectiveness of judicial protection.

Recently, the ECtHR has also held that, in some types of case, the administration has an obligation to hear a party before it takes an adverse decision and to state reasons therefor. Moreover, the ECtHR has held that a right for journalists and certain interest groups to be granted access to documents can be derived from Article 10 of the European Convention on Human Rights covering freedom of speech. Until now, these minimum requirements for good administration have not gone further than already follows from the national legislation of the Nordic countries. ${ }^{5}$

In addition to national Nordic administrations, a distinct sphere of European administration has gradually developed into a transnational and multi-level executive with increased powers and specific procedures. European administration does not necessarily refer only to the transnational administration of the EU. The national administrations of the Nordic States of the EU can also be considered as elements or tools of European administration when they apply, implement and execute EU law.

\section{The Right to Good Administration}

${ }^{5}$ Fenger, 2018. 


\subsection{Good Administration - Basic Requirements}

The Finnish Constitution expressly confers on the right to good administration the status of a basic right. Section 21 guarantees everyone the general right to have their affairs "considered appropriately and without undue delay by a lawfully competent ... public authority as well as to have a decision pertaining to his/her rights or obligations reviewed by a court of law". Express constitutional guarantees include openness of proceedings, the right to be heard, the right to receive a decision with stated grounds, and the right to appeal a decision.

The list is by no means exhaustive. Items to add to the list, for instance, might include the right to a fair and unbiased procedure, the right to compensation for harm caused by unlawful administrative activity and the right to initiate proceedings against an official infringing material or procedural norms. Based on its constitutional status, the right also serves as an interpretative guideline for applying more detailed procedural provisions. In the other Nordic countries, these rights are not guaranteed on a constitutional level but ensured by legislation.

\subsection{Procedural Guarantees}

The details of good administrative procedure are laid down in specific acts (Norway 1967; Denmark 1985; Sweden 2017; Finland 2003). ${ }^{6}$ Public authorities have a general obligation to provide service to all citizens. One of the principal applications of the obligation is the duty to ensure the actual possibility for individuals to comply with their procedural duties. Additionally, authorities and officials are obliged to supply necessary guidance and advice concerning formal requirements in individual cases. They also have to ascertain that the relevant facts are established, although the duty to provide evidence may lie on either the private party or the public authority.

In general, access to administrative procedure is quite extensive. As a rule, standing is granted to those whose own interests are at stake in a relevant manner. Anyone whose rights, interests or obligations may more substantially be affected by a decision are entitled to act as parties and consequently also to use the procedural powers of a party.

The right to be heard before a decision is made is considered one of the fundamental guarantees of good public administration. To guarantee a fair hearing, a party must be reserved an opportunity to reply to claims by others as

\footnotetext{
${ }^{6}$ Ahlström 2018; Fenger 2013; Fenger 2018; Smith \& Eckhoff 2016; Mäenpää 2016.
} 
well as to any evidence that may have an effect on the decision. The right to be heard also establishes a right to submit facts, arguments or evidence that may be relevant in resolving the matter. Parties to an administrative procedure usually also have access to a secret document if the document either has actually affected, or may affect, the outcome of the procedure, although several exceptions apply.

A party must produce evidence in support of its claim and it is the authority's duty to obtain any other evidence. The burden of proof thus lies with the private party claiming a right or a benefit or an otherwise beneficial decision. If the case has been initiated by the authority, it is duty-bound to obtain and provide evidence supporting its claims. In the latter case the burden of proof will generally lie with the authority because the decision sought is likely to be detrimental to the private party.

In Finland, administrative decisions are usually decided on the basis of a report presented by an official. The rationale for the requirement of reportbased decision-making is to enhance the correctness of administrative decisions and to extend public accountability even to the preparatory stage. The presentation consists of a document submitted by the reporting official to the administrative body or civil servant whose duty it is to take a decision in the case. The report itself focuses on the facts and merits of the case, with a survey of applicable law and a proposal for the decision. It is the duty of the reporter (or referendary) to summarize the facts of the case and the legal norms applicable as well as to express their own opinion on how the case should be decided. The reporter assumes full responsibility for the correctness of the facts and the proposal they make. Even if the decision differs from the proposal, the reporter will share responsibility for it, unless their dissenting opinion is put on record.

A decision by an administrative authority must clearly specify what rights it grants and what obligations it imposes on the party concerned, or in what other manner the case was resolved. A decision that is of detriment to a party, or that does not fully comply with what they have applied for, must also at least state the reasons for the determination by indicating the principal facts and evidence on which it was based and the statutes and provisions that were applied. A decision that qualifies for appeal must enclose appeal instructions. The main purpose of the instructions is to inform the party of the essential prerequisites for lodging an appeal in an administrative court. 


\section{Nordic Openness}

\subsection{The Principle of Openness}

The principle of access to government documents has a longstanding tradition in Sweden and Finland dating back to a constitutional enactment from 1776 (Act on the Freedom of Publishing and the Right of Access to Official Documents). While it is true that this constitutional principle of openness has been interpreted and applied in a varied manner, the principle itself has prevailed over the centuries.

The right of access to official documents is included as a fundamental right in the constitutions of the two countries. According to the Swedish Constitution "every Swedish citizen shall be entitled to have free access to official documents." Similarly, the Finnish Constitution lays down the principle of openness and freedom of information: "The documents and other records in the possession of public authorities shall be public unless their publicity has been separately restricted by Act of Parliament for compelling reasons. Everyone shall have the right to obtain information from public documents and records." Together with the guarantees of freedom of expression and freedom of information, the right of access forms a vital component of open government. Significantly, the principle of open access to administrative and judicial documents has been defined as a basic constitutional right and not merely an interpretative principle. Since access to government-held information enjoys constitutional status, the right of access may be invoked by anyone regardless of citizenship or the purpose for which that right is exercised. As a basic right it also takes precedence over ordinary legislation. For instance, if application of a statute would be in evident conflict with the right of access, the access provision in the Constitution would be given primacy in judicial proceedings. ${ }^{7}$

Whereas Denmark and Norway have no constitutional provisions ensuring openness, all Nordic countries nevertheless share the basic idea that openness in administration constitutes one of the cornerstones of democratic government and the public accountability of administrative personnel. Transparency of administration makes it possible to publicly monitor its functioning. It also strengthens public confidence in the administration. In general, government

\footnotetext{
${ }^{7}$ Mäenpää 2016.
} 
information should be considered a public asset, with the exception of personal privacy, national security matters and such other legitimate interests as may be prescribed by law. ${ }^{8}$

The methods of guaranteeing openness in administration vary depending on the character and form of administrative activity. Basically, three separate methods and areas of openness may be distinguished. First, official documents and information about the working of the administration are subject to the principle of publicity. They are presumed to be publicly accessible, unless express provisions form a restriction.

Second, it is a general obligation of the public authorities to make public information available on equal terms to all individuals requesting it. Should the matter under preparation be of such a character that it may have widespread effects, Finnish law provides that the authorities even have an active duty to make known the information about it. Third, openness extends even to the actual business of preparing and handling administrative matters by the authorities.

\subsection{Access to Government-held Information}

Detailed rules governing access to official documents are laid down in specific legislation regulating the scope and limitations of access as well as procedures for gaining access, in Sweden in the Act on access to information and secrecy (2009), in Finland in the Act on access to official documents (1999), in Norway in the Act on the right to see documents held by public entities (2006), and in Denmark in the Access to documents Act (2013). All four acts are based on the principle of general access to official documents, denoting an assumption of openness covering all documents drawn up or received by a public authority or a body exercising official functions. The authorities have not only the duty to respond to requests for access, they also have a proactive obligation to provide information and promote openness by producing and disseminating information on their activities. This is especially the case in Finland, and to a lesser extent in the other Nordic countries.

Under the presumption of openness, access to documents is the predominant rule, whereas secrecy is the exception that must in each case have an express legal basis. Everyone is presumed to have a general right to examine the contents of an official document and obtain the information contained therein, subject only to exceptions provided by law. These exceptions must also be

\footnotetext{
${ }^{8}$ Fenger and Grønnegård Christensen 2017; Jørgensen 2014.
} 
construed narrowly. If only a part of a document is secret, access must be granted to the public part of the document if this is possible without disclosing the secret part. The authorities are also under an obligation to manage their documents and data systems so as to guarantee access to public information without disclosing secret information.

To protect such legitimate interests as personal integrity, commercial confidentiality and national security, access has been restricted with regard to information about, for example, issues falling under the core areas of foreign policy, privacy, and business secrets. One reason for these restrictions is that personal data obtained in the course of government work should be protected because of their sensitivity. The operations of authorities can also not be wholly public in matters dealing with national security or crime prevention. These reasons account for the majority of express secrecy or confidentiality provisions.

In cases where the right to access is denied by a public official, sufficient reasons must be provided for refusal. All decisions taken pursuant to access legislation are reviewable in court.

\section{Access to Justice and Supervision}

\subsection{Judicial Control of Administrative Action}

In all the Nordic countries, a general right to challenge the legality of administrative decisions either in administrative courts or in courts of general competence has traditionally been regarded as a fundamental element of the system of legal protection and judicial review. The right to appeal an administrative decision is guaranteed as a basic right, as indeed is judicial reviewability of administrative acts. The review procedure is regulated either in specific acts on judicial procedure in administrative courts or in the relevant country's general act on court procedure.

In Finland and Sweden, appeals against administrative decisions by state or municipal authorities are, as a rule, lodged with administrative courts acting as court of first instance in most administrative matters. The administrative courts review inter alia tax decisions, municipal decisions, building and planning decisions, decisions concerning the environment, social welfare and healthcare decisions, staff decisions and other administrative decisions. ${ }^{9}$ In Denmark and Norway, cases concerning judicial review of administrative

\footnotetext{
${ }^{9}$ Lavin 2016; Mäenpää 2008.
} 
bodies are handled by the general courts. Moreover, especially in Denmark, a wide range of administrative appeal bodies perform tasks similar to those of the administrative courts in Sweden and Finland. The administrative appeal bodies are generally independent from the ministries. Typically, decisions are taken by a panel chaired by a judge and supplemented with specialists such as professors and representatives from interest groups. Decisions by administrative appeal bodies may be appealed to the "normal" courts.

In all the Nordic countries, an appeal for judicial review must, in many cases, be preceded by a request for reconsideration addressed to the administrative authority in question. An authority may, even at its own initiative, reconsider and correct its own decision provided that obvious errors exist in the decision or the decision is materially defective.

In Finland and Sweden, reflecting the general right to judicial review of administrative acts, the court structure also consists of two sections. The general administrative courts form a separate sector within the judiciary. The Supreme Administrative Court exercises the highest judicial power in administrative cases. The general courts, with the Supreme Court as the highest instance, have jurisdiction in civil and criminal cases. General courts lack the power to review administrative decisions and decide administrative disputes. As already mentioned, the court system in Denmark and Norway is based on a one-tier structure with a single Supreme Court that is competent in all types of cases and lower courts that similarly deal not only with judicial review of administrative acts, but also civil and criminal cases.

The right to appeal may be exercised by anyone whose right or legally protected interest is directly infringed or affected by an administrative decision or its consequences. In Finland and Sweden, decisions by municipal authorities may be appealed both by the parties immediately concerned and by any member of the municipality, irrespective of whether the decision has only the slightest impact on their rights or duties. A municipal appeal is thus a combination of both legal supervision and judicial review. In the other Nordic countries only parties to the case may ask for judicial review.

Judicial review may be directed against any act or measure of an administrative authority whereby a matter has been resolved or dismissed. To be appealable, the decision must contain a final and conclusive disposition on an individual case. This entails that no appeal is available against either initial or tentative decisions at the preparatory stage. 
As a rule, decisions by all administrative authorities are reviewable. In this respect, no distinction is drawn between administrative decisions and acts of the state. Decisions by the cabinet or the ministries may thus be subject to appeal, even if they were based on a very wide margin of discretion. However, investigation of the advisability and expediency of those decisions falls outside the scope of judicial review.

The right to a fair hearing and other guarantees of procedural fairness also apply in judicial proceedings concerning administrative cases. These guarantees include the right to be heard, the procedurally equal status of the parties and public hearing in addition to the essential right of access to a court. In administrative decision-making, the administrative authority acts as the counterpart to the appellant. The authority usually also has superior power compared to a private party. Its superior position is based on several factors, usually including the right to exercise unilateral public power, sophisticated expertise in legal and administrative issues and broader access to governmentheld data and information. Also of significance is the government authority's general proficiency in conducting the decision-making procedure and participating in judicial procedure. Against this backdrop, material equality is how the requirement of fairness is understood in the law governing administrativejudicial proceedings

In Finland and Sweden, the administrative courts are under a general obligation to actively conduct the procedure and to obtain evidence and factual information on their own initiative. The court is required to review all available evidence and resolve all claims and demands in the matter. Review of legality is also understood to extend to the exercise of discretionary powers. The court therefore has the power to investigate whether an authority has complied with general administrative principles. In Denmark and Norway, the normal rules on civil procedure apply in cases concerning judicial review. Thus, the courts will not examine ex officio whether a decision violates e.g. the principle of equality or the procedural guarantees enshrined in the Danish Public Administration act.

The court has the power to uphold or annul a challenged decision. The court can also refer a case back to the administrative authority for reconsideration. In addition to affirming or annulling the decision subject to review, the court may also partially amend it, although it may not substitute itself for the administrative authority which adopted the contested decision. 


\subsection{Supervision of Legality and the Institution of Ombudsman}

The general control of legality in public administration is the duty of specific supervisory organs or ombudsmen. The Parliamentary Ombudsman, and in Finland and Sweden also the Chancellor of Justice, have a general remit but there are also more specialized ombudsmen to guarantee e.g. equality or consumer protection. Superior administrative organs also exercise control of legality and appropriateness within the subordinate administration. It is considered to be the official duty of any superior authority to ensure that the authorities under its direction observe the law.

Administrative complaint is the ordinary procedure for any individual to bring an administrative irregularity to the knowledge of the superior authority or an Ombudsman. The scope of administrative complaints is extensive. A complaint may include a claim that a subordinate authority has acted in breach of its duties, that it has in some other manner failed to conform to the law or that other faults, irregularities or errors have been committed, or that the authority has failed to act. Besides legality, an administrative complaint may also invoke adequacy, appropriateness and compliance, with the requirements of good administration as a basis. The legality and appropriateness of administrative activity may also be examined by both the specific supervisory organs and by an Ombudsman on their own initiative.

\subsection{Accountability}

Each civil servant is individually responsible for the lawfulness of their acts in office. Official accountability extends to all decisions by an official. In Finland, anyone who has suffered a loss of rights or damage due to the unlawful act or omission of an official or a person responsible for a public duty may demand that the person concerned be punished and that the public authority or the official be ordered to compensate for damage. In Denmark, claims must be directed to the authority concerned, as it is solely up to that authority to decide whether it will bring charges or seek redress against the relevant official.

Ahlström, Kristina, Förvaltningslagen. Stockholm:Karnov 2018.

Bogdan, Mikael (ed.), Swedish Legal System. Stockholm:Norstedts 2010.

Christensen, Jens Peter, Albæk Jensen, Jørgen, and Hansen Jensen, Michael, Dansk Statsret, DJØF 2012.

Fenger, Niels, Forvaltning og Fællesskab, DJØF 2004. 
Fenger, Niels, Forvaltningsloven med kommentarer (a commentary to the Danish Public Administration Act), DJØF 2013.

Fenger, Niels, Borgeren og digitalisert forvaltning - hvor går vi?, 40. nordiske jurist $\neg$ møde, Oslo 2014, bind 1, s. 89.

Fenger, Niels, and Grønnegård Christensen, Jørgen, Åbenhed og fortrolighed i den ministerielle beslutningsproces En redegørelse for offentlighedslovgivningens beskyttelse af den politisk-administrative beslutningsproces i udvalgte europæiske lande (Openness and confidentiality in the ministerial decision making process), Copenhagen 2017.

Fenger, Niels, Forvaltningsret, DJØF 2018.

Graver, Hans Petter, Alminnelig forvaltningsrett (General Administrative Law), Universitetsforlaget: Oslo 2015.

Jørgensen, Oluf, Access to Information in the Nordic Countries. Gothenburg: Nordicom 2014.

Lavin, Rune, Förvaltningsprocessrätt (Administrative Judicial Procedure). Wolters Kluwer 2016.

Marcusson, Lena (ed.), Offentligrättsliga principer (Principles of Public Law). Uppsala: Iustus 2005.

Mäenpää, Olli, Hallinto-oikeus (Administrative Law). Helsinki:Alma Talent 2018.

Mäenpää, Olli, Hallintolaki ja hyvän hallinnon takeet. (Administrative Procedure Act). Edita: Helsinki 2016.

Mäenpää, Olli, Julkisuusperiaate (Access to Official Information). Talentum Pro: Helsinki 2016.

Mäenpää, Olli, Hallintoprosessioikeus (Judicial Procedure in Administrative Courts). WSOYPro: Helsinki 2008.

Nergelius, Joakim, Constitutional Law in Sweden. Wolters Kluwer:2011.

Nuotio, Kimmo (ed.): Introduction to Finnish Law and Legal Culture. Helsinki: Forum Iuris 2012.

Revsbech, Karsten, Forvaltningsret Almindelige Emner (General Administrative Law), DJØF 2016.

Smith, Eivind, and Eckhoff, Torstein, Forvaltningsrett (Administrative Law), Akademika: Oslo 2016.

Strömberg, Håkan \& Lundell, Bengt, Allmän förvaltningsrätt (General Administrative Law). Malmö: Liber 2014. 